\title{
PI3K/Akt/mTOR signaling pathway and targeted therapy for glioblastoma
}

\author{
Xiaoman $\mathrm{Li}^{1, *}$, Changjing Wu ${ }^{1, *}$, Nianci Chen ${ }^{2}$, Huadi $\mathrm{Gu}^{3}$, Allen Yen ${ }^{4}$, Liu Cao ${ }^{1}$, \\ Enhua Wang ${ }^{3,5}$ and Liang Wang ${ }^{3,5}$ \\ ${ }^{1}$ Key Laboratory of Medical Cell Biology, Ministry of Education, China Medical University, Shenyang, China \\ ${ }^{2}$ Class 9 of the 97th Clinical Medicine of Seven-Year Program, China Medical University, Shenyang, China \\ ${ }^{3}$ Department of Pathology, The College of Basic Medical Sciences, China Medical University, Shenyang, China \\ ${ }^{4}$ School of Medicine, The University of Texas Southwestern Medical Center, Dallas, Texas, United States of America \\ ${ }^{5}$ Department of Pathology, The First Affiliated Hospital of China Medical University, Shenyang, China \\ * These authors have contributed equally to this work
}

Correspondence to: Liang Wang, email: wang_liang@live.com

Keywords: glioblastoma, EGFR, PI3K/Akt/mTOR pathway, targeted therapy

Received: December 05, 2015 Accepted: February 24, 2016

Published: March 07, 2016

\section{ABSTRACT}

Glioblastoma multiform (GBM) is the most common malignant glioma of all the brain tumors and currently effective treatment options are still lacking. GBM is frequently accompanied with overexpression and/or mutation of epidermal growth factor receptor (EGFR), which subsequently leads to activation of many downstream signal pathways such as phosphatidylinositol 3-kinase (PI3K)/Akt/rapamycinsensitive mTOR-complex (mTOR) pathway. Here we explored the reason why inhibition of the pathway may serve as a compelling therapeutic target for the disease, and provided an update data of EFGR and PI3K/Akt/mTOR inhibitors in clinical trials.

\section{INTRODUCTION}

\section{Glioblastoma multiform}

Glioblastoma multiform (GBM), WHO grade IV, is the most common and aggressive glioma of all primary brain tumors, exhibiting a high rate of recurrence and poor prognosis due to the invasive nature of the tumor $[1,2]$. Considering the location and diffusely infiltrating nature of the tumor, complete surgical resections are challenging. Standard therapy for GBM is radiation plus the chemopeutic agent temozolomide (TMZ). The cytotoxicity of TMZ is thought to be primarily due to alkylation of DNA hence leading to DNA damage and tumor cell death [3]. However, the activation of PI3K/ $\mathrm{Akt} / \mathrm{mTOR}$ pathway leads to the development of drug resistance thereby dampening the therapeutic effect of TMZ [4]. The five year survival rate for glioblastoma is less than $5 \%$ in adults [5-7]. The occurrence of GBM is frequently associated with molecular changes in epidermal growth factor receptor (EGFR) and phosphatidylinositol 3-kinase (PI3K)/Akt/rapamycin-sensitive mTORcomplex (mTOR) pathways. The frequency of genetic alterations such as overexpression EGFR, activating mutations of PI3CA (p110) or PIK3R1 (P85), or loss of PTEN expression has been estimated to around $88 \%$ [812]. GBM patients with an activated PI3K/Akt/mTOR pathway also have poor prognosis than patients without oncogenic activation of the pathway [13]. Therefore, inhibitors targeting EGFR and PI3K/Akt/mTOR pathway have emerged as potential treatment for GBM [14-18]. Currently, a series of inhibitors targeting EGFR and PI3K/ Akt/mTOR pathway are evaluated in preclinical and clinical studies as single agent or in combination with the traditional treatment [19]. It is of particular interest to explore whether those inhibitors are effective to restore the therapeutic sensitivity.

\section{EGFR and PI3K/Akt/mTOR signal transduction pathway}

EGFR is a type of receptor tyrosine kinases (RTKs), playing a central role in cell division, migration, adhesion, differentiation and apoptosis [20, 21]. EGFR comprises of extracellular ligand binding domain, transmembrane domain and intracellular tyrosine kinase domain. Upon binding to various of ligands, such as EGF and 
TGF $\alpha$, EGFR is activated through homodimerization or heterdimerization on the cell surface and subsequently leads to the phosphorylation of its intracellular tyrosine kinase domain [22]. The activation of EGFR results in activation of multiple downstream signal transduction pathways such as PI3K/Akt/mTOR pathway [23].

Members of the PI3K family are lipid kinases involved in multiple cellular process, including proliferation, differentiation, migration, metabolism and survival [24]. PI3K is generally classified into three classes according to their substrate specificity and subsequence homology, among which, the class I is most vital to the tumorigenesis. Class I consisted of a catalytic subunit $\mathrm{p} 110(\alpha, \beta, \gamma)$ and a regulator subunit p85. A fourth $\mathrm{p} 110$ isoform $(\mathrm{p} 110 \delta)$ is paired with the $\mathrm{p} 101$ regulatory subunit in class IB PI3Ks. Upon ligand binding, phosphorylated tyrosine residing in activated RTKs will bind to $\mathrm{p} 85$. The subsequent conformation change will release the catalytic subunit p110 [25], where activated p110 phosphorylated the phosphatidy-linositol-3, 4-bisphosphate (PIP2) into the second messenger phosphatidylinositol-3, 4, 5-bisphosphate (PIP3). This reaction can be reversed by the PI3K antagonist PTEN (phosphatase and tensin homolog deleted on chromosome ten) [26]. Subsequently,
PIP3 will recruit the downstream Akt to inner membranes and phosphorylates Akt on its serine/threonine kinasesites (Thr308 and Ser473) [27, 28]. Activated Akt is involved in the downstream mTORC1 mediated response to biogenesis of protein and ribosome.

In PI3K pathway, mTOR acts as both a downstream effector and an upstream regulator [29, 30]. mTOR resides in rapamycin-sensitive mTOR-complex (mTORC1) and a rapamycin-insensitive complex (mTORC2) [31, 32]. The activated Akt inhibits tuberous sclerosis complex (TSC) $1 / 2$ activity, thereby initiate the mTORC1-mediate signaling pathway, involving in the phosphorylation of ribosomal protein S6 kinase (pS6k), eukaryotic initiation factor 4E (eIF4E) and eukaryotic initiation factor binding protein 1(4EBP1), which participate in protein translation, ribosome biogenesis as well as cell growth [33, 34]. The mTORC2 phosphorylates Akt at Ser-473, and then further takes part in cell survival, metabolism, proliferation, and cytoskeletal organization $[31,35]$. Within PI3K signaling pathway, another important molecule is PTEN. As clinical research revealed, the EGFR or PTEN mutation would lead to continuous activation of PI3K/Akt/mTOR signaling pathway, thereby contributing to the tumorigenesis and cancer therapy resistance (Figure 1).

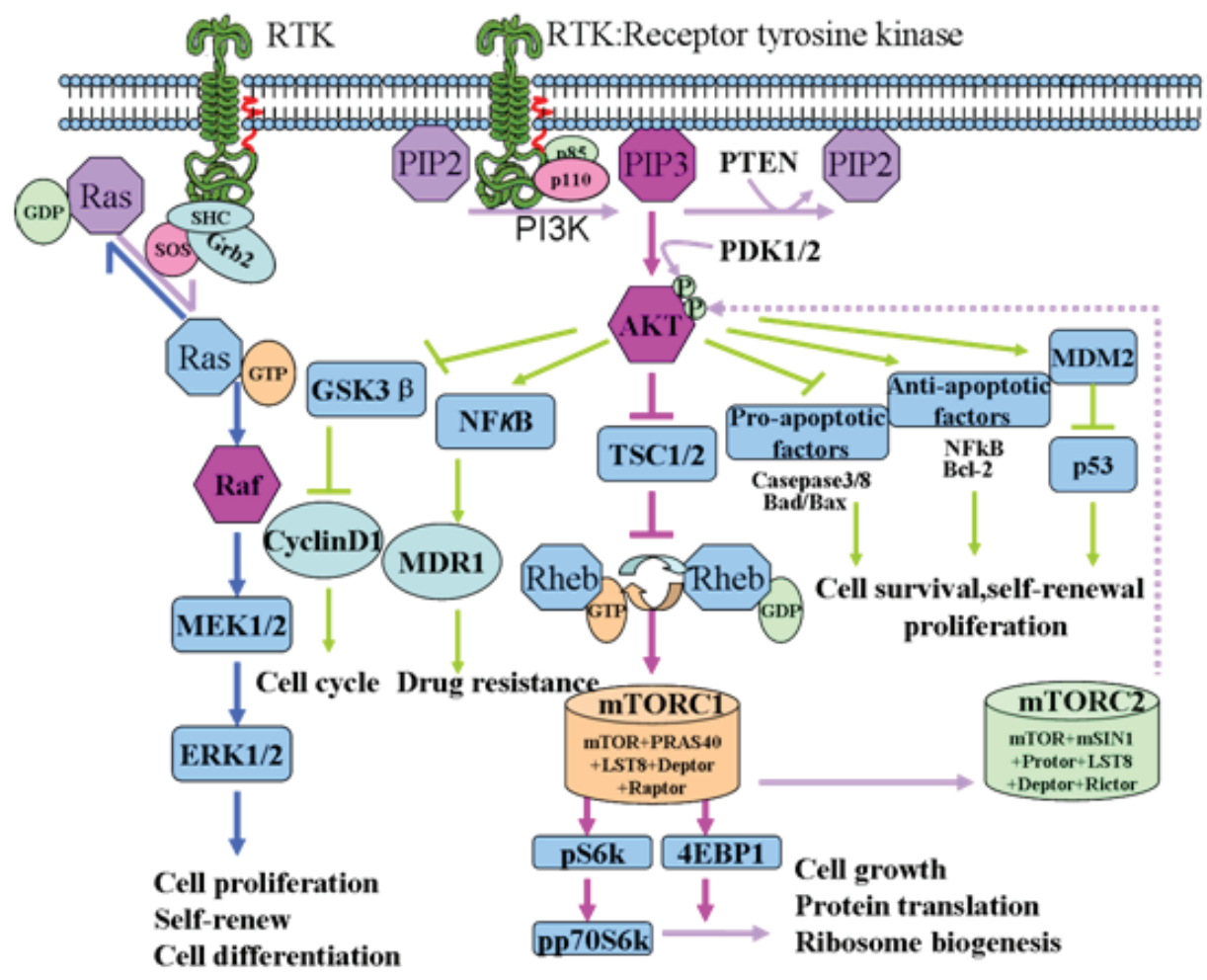

Figure 1: Schematic representation of the PI3K/Akt/mTOR signaling pathway. Upon relevant ligand binding, RTK, such as EGFR, is activated and subsequently inducing a series of cascade reaction. First, the regulator subunits of PI3K, p85, dimerize and release its catalytic subunit p110. p110 enables the membrane protein PIP2 to phosphorylate into PIP3. PIP3 begins to recruit the downstream Akt to inner membranes and phosphorylated the serine/threonine kinase (Thr308 and Ser473) sites by phosphoinositide-dependent kinase 1/2 (PDK1/2). Activated Akt is involved in the downstream mTORC1 mediated response to biogenesis of protein and ribosome. Besides that, activated Akt is also involved in the regulation of cell cycle and pro-apoptotic and anti-apoptotic factors mediated choices of cell apoptosis and survival. Additionally, it is also involved in the NFKB/MDR1 mediated drug resistance. 
Table 1: Ongoing clinical trials in brain tumors targeting EGFR.

\begin{tabular}{|c|c|c|c|c|c|c|}
\hline Drug & Targets & $\begin{array}{l}\text { Combination } \\
\text { Partner }\end{array}$ & Patient group & Phase & State & Trail ID \\
\hline \multirow{6}{*}{ Gefitinib } & EGFR & & recurrent glioblastoma & II & completed & NCT00250887 \\
\hline & EGFR & & GBM & II & completed & NCT00014170 \\
\hline & EGFR & & GBM & II & completed & NCT00016991 \\
\hline & EGFR & & $\begin{array}{l}\text { brain and central nervous } \\
\text { system tumors }\end{array}$ & II & completed & NCT00025675 \\
\hline & EGFR & radiation & GBM & $\mathrm{I} / \mathrm{II}$ & completed & NCT00052208 \\
\hline & EGFR & radiation & GBM & II & completed & NCT00238797 \\
\hline $\begin{array}{l}\text { Gefitinib, } \\
\text { Temozolomide }\end{array}$ & EGFR & & $\begin{array}{l}\text { brain and central nervous } \\
\text { system tumors }\end{array}$ & $\mathrm{I}$ & completed & NCT00027625 \\
\hline $\begin{array}{l}\text { Gefitinib, } \\
\text { Irinotecan }\end{array}$ & $\begin{array}{l}\text { EGFR, } \\
\text { topoismerase I }\end{array}$ & & refractory solid tumor & $\mathrm{I}$ & completed & NCT00132158 \\
\hline \multirow{6}{*}{ Erlotinib } & EGFR & & GBM & II & completed & \begin{tabular}{|l} 
NCT00337883 \\
\end{tabular} \\
\hline & EGFR & & GBM & II & unknown & NCT00054496 \\
\hline & EGFR & & $\begin{array}{l}\text { GBM and other brain } \\
\text { tumors }\end{array}$ & I/II & ongoing & NCT00045110 \\
\hline & EGFR & & GBM & $\mathrm{I} / \mathrm{II}$ & completed & NCT00301418 \\
\hline & EGFR & radiation & $\begin{array}{ll}\text { brain/central nervous } \\
\text { system tumors }\end{array}$ & $\mathrm{I} / \mathrm{II}$ & completed & NCT00124657 \\
\hline & EGFR & $\begin{array}{l}\text { cytoreductive } \\
\text { surgery }\end{array}$ & \begin{tabular}{|ll}
$\begin{array}{l}\text { recurrent malignant } \\
\text { gliomas }\end{array}$ \\
\end{tabular} & & ongoing & NCT01257594 \\
\hline \multirow{3}{*}{$\begin{array}{l}\text { Erlotinib, } \\
\text { Temozolomide }\end{array}$} & EGFR & radiation & GBM, gliosarcoma & II & completed & NCT00187486 \\
\hline & EGFR & radiation & GBM & II & completed & NCT00274833 \\
\hline & EGFR & radiation & GBM & II & completed & NCT00039494 \\
\hline $\begin{array}{l}\text { Erlotinib, } \\
\text { Temozolomide, } \\
\text { Carmustine } \\
\end{array}$ & EGFR & & $\begin{array}{l}\text { glioblastoma, } \\
\text { gliosarcoma }\end{array}$ & II & completed & NCT00086879 \\
\hline $\begin{array}{l}\text { Erlotinib, } \\
\text { Bevacizumab. }\end{array}$ & EGFR,VEGF & & $\begin{array}{l}\text { glioblastoma, } \\
\text { gliosarcoma }\end{array}$ & II & completed & NCT00671970 \\
\hline $\begin{array}{l}\text { Erlotinib } \\
\text { Bevacizumab, } \\
\text { Temozolomide, }\end{array}$ & EGFR, VEGF & radiation & GBM & II & ongoing & NCT00720356 \\
\hline $\begin{array}{l}\text { Erlotinib, } \\
\text { Sorafenib }\end{array}$ & $\begin{array}{l}\text { EGFR, RAF, } \\
\text { VEGFR }\end{array}$ & & GBM & II & completed & NCT00445588 \\
\hline $\begin{array}{l}\text { Erlotinib, } \\
\text { Dasatinib }\end{array}$ & EGFR,SRC & & GBM & I & completed & NCT00609999 \\
\hline Dacomitinib & EGFR & & recurrent glioblstoma & II & ongoing, & NCT01520870 \\
\hline Afatinib & EGFR & & refractory solid tumors & II & completed & NCT00875433 \\
\hline AEE788 & EGFR & & GBM & I/II & completed & NCT00116376 \\
\hline Lapatinib & EGFR & & GBM & I/II & completed & NCT00099060 \\
\hline Lapatinib & EGFR & & malignant brain tumors & II & completed & NCT00107003 \\
\hline Nimotuzumab & EGFR & & GBM & & completed & NCT00561873 \\
\hline $\begin{array}{l}\text { Nimotuzumab, } \\
\text { Temozolomide }\end{array}$ & EGFR & radiation & GBM & III & completed & NCT00753246 \\
\hline $\begin{array}{lr}\text { EGFR } & \text { Bi- } \\
\text { armed } & \\
\text { Autologous } & \mathrm{T} \\
\text { cells } & \\
\end{array}$ & EGFR, CD3 & & $\begin{array}{l}\text { glioblastoma, } \\
\text { gliosarcoma recurrent } \\
\text { neoplasm }\end{array}$ & $\mathrm{I} / \mathrm{II}$ & $\begin{array}{l}\text { not yet } \quad \text { yet } \\
\text { recruiting }\end{array}$ & NCT02521090 \\
\hline AMG 595 & EGFR & & GBM & I & ongoing & NCT01475006 \\
\hline Sym004 & EGFR & & recurrent glioblastoma & II & ongoing & NCT02540161 \\
\hline $\begin{array}{l}\text { Cetuximab, } \\
\text { Temozolomide }\end{array}$ & EGFR & radiation & GBM & $\mathrm{I} / \mathrm{II}$ & unknown & NCT00311857 \\
\hline
\end{tabular}




\begin{tabular}{|l|l|l|l|l|l|l|}
\hline $\begin{array}{l}\text { Cetuximab, } \\
\text { Bevacizumab, } \\
\text { Irinotecan }\end{array}$ & $\begin{array}{l}\text { EGFR,VEGF, } \\
\text { topoismerase I }\end{array}$ & GBM & II & completed & NCT00463073 \\
\hline $\begin{array}{l}\text { Afatinib, } \\
\text { Temozolomide }\end{array}$ & EGFR & radiation & GBM & I & ongoing & NCT00977431 \\
\hline $\begin{array}{l}\text { Afatinib, } \\
\text { Temozolomide }\end{array}$ & EGFR & & GBM & II & ongoing & NCT00727506 \\
\hline
\end{tabular}

Clinical data related to the EGFR was searched until Nov, 2015.

Table 2: Ongoing clinical trials in brain tumors targeting PI3K.

\begin{tabular}{|l|l|l|l|l|l|l|}
\hline Drug & Targets & $\begin{array}{l}\text { Combination } \\
\text { partner }\end{array}$ & Patient group & Phase & State & Trail ID \\
\hline \multirow{3}{*}{ BKM120 } & \multirow{3}{*}{ Pan-PI3K } & surgery & recurrent glioblastoma & II & ongoing, & NCT01339052 \\
\cline { 3 - 7 } & & Bevacizumab & relapsed/refractory GBM & I/II & recruiting & NCT01349660 \\
\cline { 3 - 7 } & & LDE225 & advanced solid tumor & I & completed & NCT01576666 \\
\cline { 3 - 7 } & INC280 & recurrent glioblastoma & I/II & recruiting & NCT01870726 \\
\hline $\begin{array}{l}\text { BKM120, } \\
\text { Temozolomide }\end{array}$ & Pan-PI3K & radiation & glioblastoma & I & ongoing & NCT01473901 \\
\hline PX-866 & Pan-PI3K & & GBM & II & completed & NCT01259869 \\
\hline
\end{tabular}

Clinical data related to the EGFR was searched until Nov, 2015.

\section{THE DEVELOPMENT OF TARGETED THERAPY TOWARDS EGFR AND PI3K/ AKT/MTOR}

\section{EGFR inhibitors}

EGFR alteration, including overexpression or gene amplification, is the most frequent form of genetic mutation, occurred in $40-50 \%$ of glioblastomas [36, 37]. Logically, EGFR is a promising target for the treatment of GBM. Though promising results was shown in preclinical data, targeting EGFR in clinical trials revealed marginal effects. An overview of ongoing clinical trial in GBM is summarized in Table 1. Information about clinical trials has been retrieved from www.clinicaltrials.gov. In the clinical trial NCT00250887, the effectiveness of EGFR tyrosine kinase inhibitor Gefitinib was tested in recurrent glioblastoma. Though EGFR was successfully -dephosphorylated, the downstream target remains constitutively active. Therefore the effectiveness was unsatisfactory [38]. Erlotinib, another selective EGFR inhibitor, also showed minimal effect to treat the recurrent glioblastoma (NCT00086879) [39]. Other than single agent treatment, combination therapy was also explored. When Erlotinib was combined with TMZ and radiotherapy in a phase I/II trial, no sign of benefit was showed compared with TMZ controls (NCT00039494) [40, 41]. Additionally, the combination therapy of Erlotinib with VEGF antibody also shows no obvious survival benefit [42]. The failure of targeting EGFR is generally due to the hyperactivation of downstream PI3K/Akt signaling, so the downstream components represents an attractive target for the treatment of malignant brain tumors.

\section{PI3K inhibitors}

Currently, the PI3K inhibitors as a single agent or combined with other therapies are being tested in a number of clinical trials (Table 2) [43]. There are panPI3K inhibitors and isoform specific PI3K inhibitors [14]. The first generation of pan-PI3K inhibitors is represented by wortmannin and LY294002 [44, 45]. They have showed anti-cancer effect in vivo and in vitro [46-49]. However, both drugs were halted at preclinical studies due to the toxicity, poor pharmacodynamics and selectivity. A new generation of PI3K inhibitors, BKM120 and PX-866, exhibit better drug properties such as high stability and low side effects $[50,51]$. BKM120 has anti-proliferative and pro-apoptotic activity in a number of tumor cell lines, human tumor xenograft models and cancer patients bearing PI3K activating mutations [52]. BKM120 was smoothly passed phase I clinical trial and now is undergoing phase II trial among patients with recurrent glioblastoma and activated PI3K pathway (NCT01339052) (Table 2) [50]. At present, BKM120 is also undergoing several clinical trials in combination with radiation (NCT01473901), anti-VEGF monoclonal antibody Bevacizumab (NCT01349660), LDE225 (NCT01576666) and INC280 (NCT01870726) [53]. PX866 could bind with the catalytic domain of ATP and it acts as an irreversible inhibitor. Though PX-866 could increase median survival time of the animals and show significant anti-tumor activity in GBM xenograft models $[54,55]$, the recent completed clinical study showed the overall response rate was low (NCT01259869) [56]. 
Table 3: Ongoing clinical trials in brain tumors targeting mTOR.

\begin{tabular}{|c|c|c|c|c|c|c|}
\hline Drug & Targets & $\begin{array}{l}\text { Combination } \\
\text { Partner }\end{array}$ & Patient group & Phase & State & Trail ID \\
\hline \multirow[b]{2}{*}{ Sirolimus } & \multirow[b]{2}{*}{$\mathrm{mORC} 1$} & & GBM & $\mathrm{I} / \mathrm{II}$ & completed & NCT00047073 \\
\hline & & vaccine therapy & \begin{tabular}{|l|} 
NY-ESO-1 expressing \\
solid tumors
\end{tabular} & I & ongoing & NCT01522820 \\
\hline \multirow{2}{*}{$\begin{array}{l}\text { Sirolimus, } \\
\text { Erlotinib }\end{array}$} & \multirow{2}{*}{$\begin{array}{l}\text { mTORC1 } \\
+ \text { EGFR }\end{array}$} & & glioblastoma & II & completed & NCT00672243 \\
\hline & & & malignant glioma & $\mathrm{I} / \mathrm{II}$ & completed & NCT00509431 \\
\hline $\begin{array}{l}\text { Sirolimus, } \\
\text { Vandetanib }\end{array}$ & $\begin{array}{l}\text { mTORC1 } \\
+ \text { VEGF }\end{array}$ & & glioblastoma & I & completed & NCT00821080 \\
\hline \multirow{3}{*}{$\begin{array}{l}\text { Everolimus, } \\
\text { Temozolomide }\end{array}$} & \multirow{3}{*}{ mTORC1 } & & GBM & $\mathrm{I}$ & completed & NCT00387400 \\
\hline & & radiation & GBM & $\mathrm{I} / \mathrm{II}$ & ongoing & NCT01062399 \\
\hline & & radiation & glioblastoma & $\mathrm{I} / \mathrm{II}$ & ongoing, & NCT00553150 \\
\hline $\begin{array}{l}\text { Everolimus, } \\
\text { Gefitinib }\end{array}$ & $\begin{array}{l}\text { mTORC1+ } \\
\text { EGFR }\end{array}$ & & progressive GBM & I/II & completed & NCT00085566 \\
\hline $\begin{array}{l}\text { Everolimus, } \\
\text { Gleevec, } \\
\text { Hydroxyurea } \\
\end{array}$ & $\begin{array}{l}\text { mTORC1, } \\
\text { PDGFR } \\
\text { BCR-AbI } \\
\end{array}$ & & & I & completed & NCT00613132 \\
\hline $\begin{array}{l}\text { Everolimus, } \\
\text { Temozolomide } \\
\text { Bevacizumab }\end{array}$ & $\begin{array}{l}\text { mTORC1, } \\
\text { VEGF }\end{array}$ & radiation & GBM & II & completed & NCT00805961 \\
\hline $\begin{array}{l}\text { Everolimus, } \\
\text { AEE788 }\end{array}$ & \begin{tabular}{|l|} 
mTORC1, \\
EGFR,VEGFR
\end{tabular} & & GBM & $\mathrm{I} / \mathrm{II}$ & completed & NCT00107237 \\
\hline $\begin{array}{l}\text { Everolimus, } \\
\text { BEZ235 }\end{array}$ & $\begin{array}{l}\mathrm{mTOR}, \\
\mathrm{PI} 3 \mathrm{~K} / \mathrm{mTOR}\end{array}$ & & Cancer & I/II & unknown & NCT01508104 \\
\hline $\begin{array}{l}\text { Everolimus, } \\
\text { Sorafenib }\end{array}$ & $\begin{array}{l}\text { mTORC1, } \\
\text { RAF }\end{array}$ & & \begin{tabular}{|l|l|}
$\begin{array}{l}\text { recurrent high-grade } \\
\text { gliomas }\end{array}$ \\
\end{tabular} & I/II & recruiting & NCT01434602 \\
\hline \multirow{3}{*}{ Temsirolimus } & \multirow{3}{*}{ mTORC1 } & & $\begin{array}{l}\text { brain and central nervous } \\
\text { system tumors }\end{array}$ & I & completed & NCT00784914 \\
\hline & & & $\begin{array}{l}\text { brain and central nervous } \\
\text { system tumors }\end{array}$ & I/II & completed & NCT00022724 \\
\hline & & & GBM & II & completed & NCT00016328 \\
\hline $\begin{array}{l}\text { Temsirolimus, } \\
\text { Doxorubicin }\end{array}$ & mTORC1 & & $\begin{array}{|lr|}\text { resistant } & \text { solid } \\
\text { malignancies }\end{array}$ & I & completed & NCT00703170 \\
\hline $\begin{array}{l}\text { Temsirolimus, } \\
\text { Docetaxel }\end{array}$ & mTORC1 & & \begin{tabular}{|lr} 
resistant \\
malignancies
\end{tabular} & I & completed & NCT00703625 \\
\hline \multirow{2}{*}{$\begin{array}{l}\text { Temsirolimus, } \\
\text { Temozolomide, }\end{array}$} & \multirow{2}{*}{ mTORC1 } & \multirow{2}{*}{ radiation } & GBM & $\mathrm{I}$ & completed & NCT00316849 \\
\hline & & & glioblastoma & II & ongoing & NCT01019434 \\
\hline $\begin{array}{l}\text { Temsirolimus, } \\
\text { Sorafenib, } \\
\text { Erlotinib, } \\
\text { Tipifarnib } \\
\end{array}$ & $\begin{array}{l}\text { mTORC1 } \\
+ \text { EGFR }\end{array}$ & & \begin{tabular}{|l} 
recurrent GBM or \\
gliosarcoma
\end{tabular} & $\mathrm{I} / \mathrm{II}$ & completed & NCT00335764 \\
\hline $\begin{array}{l}\text { Temsirolimus, } \\
\text { Erlotinib, }\end{array}$ & $\begin{array}{l}\text { mTORC1 } \\
+ \text { EGFR }\end{array}$ & & $\begin{array}{l}\text { recurrent malignant } \\
\text { glioma }\end{array}$ & I/II & completed & NCT00112736 \\
\hline \multirow[b]{2}{*}{$\begin{array}{l}\text { Temsirolimus, } \\
\text { Perifosine }\end{array}$} & \multirow[b]{2}{*}{$\begin{array}{l}\mathrm{mTORC} 1 \\
+\mathrm{Akt}\end{array}$} & & malignant gliomas & I/II & ongoing & NCT01051557 \\
\hline & & \begin{tabular}{|l|} 
cytoreductive \\
surgery, Immuno- \\
suppressant
\end{tabular} & brain tumor & II & recruiting & NCT02238496 \\
\hline $\begin{array}{l}\text { Temsirolimus, } \\
\text { Bevacizumab }\end{array}$ & $\begin{array}{l}\text { mTORC1 } \\
+ \text { VEGF }\end{array}$ & & GBM & II & completed & NCT00800917 \\
\hline Ridaforolimus & mTOR & & Glioma & $\mathrm{I}$ & completed & NCT00087451 \\
\hline CC-115 & $\begin{array}{l}\text { DNA-PK/ } \\
\text { mTOR }\end{array}$ & & advanced solid tumor & I/II & ongoing & NCT01353625 \\
\hline $\mathrm{CC}-223$ & $\begin{array}{l}\text { dual mTOR } \\
\text { inhibitor }\end{array}$ & $\begin{array}{l}\text { surgery, } \\
\text { supportive care }\end{array}$ & advanced solid tumor & I/II & ongoing & NCT01177397 \\
\hline $\begin{array}{l}\text { XL765, } \\
\text { Temozolomide }\end{array}$ & $\begin{array}{ll}\text { dual } \\
\text { mTOR }\end{array}$ & radiation & GBM & I & completed & NCT00704080 \\
\hline
\end{tabular}




\begin{tabular}{|l|l|l|l|l|l|l|}
\hline $\begin{array}{l}\text { XL147, } \\
\text { XL765 }\end{array}$ & $\begin{array}{l}\text { PI3K, PI3K/ } \\
\text { mTOR }\end{array}$ & $\begin{array}{l}\text { glioblastoma, } \\
\text { astrocytoma, Grade IV }\end{array}$ & I & completed & NCT01240460 \\
\hline PKI-587 & $\begin{array}{l}\text { PI3K, class IA, } \\
\text { mTORC1/C2 }\end{array}$ & & solid tumor & I & completed & NCT00940498 \\
\hline AZD8055 & mTOR & & GBM & I & completed & NCT01316809 \\
\hline INK128 & mTORC1/2 & Bevacizumab & $\begin{array}{l}\text { recurrent glioblastoma, } \\
\text { advanced solid tumors }\end{array}$ & I & recruiting & NCT02142803 \\
\hline $\begin{array}{l}\text { Pembrolizumab, } \\
\text { Pictilisib, } \\
\text { NVP-BEZ235, } \\
\text { Ipatasertib }\end{array}$ & $\begin{array}{l}\text { PI3K } / \delta, \\
\text { Pkt1/2/3 }\end{array}$ & Glioblastoma & I/II & & NCT02430363 \\
\hline $\begin{array}{l}\text { Metformin } \\
\text { Temozolomide }\end{array}$ & mTOR & & GBM & I & ongoing & NCT01430351 \\
\hline Metformin & mTOR & radiation & recurrent brain tumor & I & recruiting & NCT02149459 \\
\hline
\end{tabular}

Clinical data related to the EGFR was searched until Nov, 2015.

\section{Akt inhibitors}

Akt is a central player in the EGFR/PI3K signaling pathways. Evidence shows that Akt play an important role in tumor proliferation and radiosensitivity [57]. One of the most promising Akt inhibitor, perifosine, inhibits Akt activity by preventing its translocation to the cell membrane $[58,59]$. Currently, perifosine is being clinically tested in a number of different cancers $[60,61]$. Perifosine has several drawbacks such as limited ability to penetrate blood-brain-barrier (BBB) and gastrointestinal side effects. A phase II trial of perifosine in recurrent GBM was ongoing but only marginal effect was shown (NCT00590954).

\section{mTOR inhibitors}

As downstream targets of phosphorylated Akt, inhibition of mTOR would also be another therapeutic approach to reduce the effects of constitutively activate Akt in GBM. mTORC1 inhibitors mainly contain rapamycin (sirolimus) and its analogues, such as RAD001 (everolimus), CCL-779 (temsirolimus) and AP23573 (ridaforolimus) [62]. Rapamycin inactivate mTORC1 through altering the conformation of the kinase. Though rapamycin and its analogues exhibit efficacy of mTOR inhibitors in both in vitro and in vivo models [63, 64], they would arose hyperactivation of Akt and mTORC2 by some feedback loop and pathway crosstalk [65]. Rapamycin shows anti-tumor activity in a phase I trial for patients with recurrent PTEN-deficient glioblastoma (NCT00047073) [66]. Unfortunately, phase II clinical trials for rapamycin analogs fail to achieve promising results (NCT00515086, NCT00016328, NCT00022724, and NCT00087451) [67-71]. The limited efficacy might result from the feedback loops and crosstalk with other pathways. Recently, more exploration was focusing on the combination treatment of rapamycin analogs with other modalities [71]. The combination of EGFR inhibitor erlotinib with sirolimus or temsirolimus was tested in clinical trials (NCT00112736 and NCT0062243). However, either of trial shows promising results $[72,73]$. A phase II study of everolimus with bevacizumab as part of first-line modality therapy for glioblastoma was feasible and efficacious (NCT00805961) [74], further studies are still need. As combined inhibition of Akt and mTOR by perfosine and temsirolimus inhibited murine glioblastoma growth no matter PTEN status, a phase I/II trial in recurrent high-grade gliomais ongoing (NCT01051557) $[75,76]$. Metformin is a widely prescribed antidiabetic drug and many studies indicate that metformin inhibits cancer proliferation through the inhibition of mTOR [77]. The efficacy of metformin on glioblastoma was tested in clinical trial NCT01430351 and NCT02149459. In NCT02149459, metformin was combined with radiotherapy. In NCT01430351, metformin was combined with TMZ. Both of the trials are still in phase I state.geting specifically mTORC 2 could thereby be a better approach, since it would directly block Akt phosphorylation without perturbing the mTORC1-dependent feedback loops [78, 79]. In contrast to mTORC $1, \mathrm{mTORC} 1 / 2$ inhibitors can restrain Akt phosphorylation at Ser473, thus also inhibit mTORC2 at the same time [63]. AZD8055 is a potent small molecular ATP-competitive inhibitor. In vivo, AZD8055 reduced S6 and Akt phosphorylation thereby leading to the reduction of tumor growth [80]. It is implicated that AZD8055 may provide a more promising therapeutic strategy than rapamycin and analogues [81]. Currently AZD8055 has completed the phase I clinical trials (NCT01316809).

\section{PI3K/mTOR dual inhibitor}

Since mTORC1 inhibitors could induce the loss of feedback inhibition of PI3K activation, drugs targeting PI3K and mTOR kinase simultaneously thereby become a superior option [82]. Active site ATP-competitor is a class of dual PI3K-mTOR inhibitor, which structurally 
targets the kinase domains of both PI3K and mTOR. PI103 was the first dual mTOR/PI3K inhibitors that inhibited mTOR in an ATP-competitive manner [83]. In vivo study showed that PI-103 led to G0-G1 cell cycle arrest thereby inhibiting the proliferation and invasion of tumor cells [84]. However, PI-103 was halted in the preclinical period due to the poor pharmacokinetic properties. NVP-BEZ235 is a promising $\mathrm{PI} 3 \mathrm{~K} / \mathrm{mTOR}$ dual inhibitor exhibiting improved anti-tumor potential compared to rapamycin analogs [85-88]. In preclinical test, study demonstrated that NVP-BEZ235 significantly prolonged the survival of tumor bearing animals without eliciting obvious toxicity [89]. Therefore, NVP-BEZ235 has entered phase I and phase II clinical trials with everolimus in patients with malignant solid tumors (NCT01508104). Other dual PI3K and mTOR inhibitors, such as PKI-587 and XL765 , have shown favorable activity in preclinical settings. XL-765 has completed the trial in combination with radiotherapy and $\mathrm{TMZ}$ for $\mathrm{GBM}$ as well as in subjects with recurrent GBM (NCT00704080). PKI-587 and XL765 have recently completed the phase I clinical trials for the treatment of solid tumors (NCT00940498) and recurrent $\mathrm{GBM}$ who are candidates for surgical resection (NCT01240460).

\section{THE LIMITED FACTORS OF TARGETED THERAPY BASED ON PI3K SIGNALING PATHWAY}

Though more and more PI3K/Akt/mTOR targeted drugs emerge, they are still undergoing preclinical or clinical trials. Targeted therapy for GBM has yet to demonstrate an appreciable clinical survival benefit. At present, here are some possible reasons for the limited therapy effect: (1) Blood Brain Barrier. It's the most likely explanation for why targeted drugs cannot reach effective concentrations (2) Heterogeneity of GBM. No doubt the outcome of drug efficacy is much influenced by the genetic background of the tumor. In malignant tumors, molecular phenotype of the same tumor in different location may totally diverse and molecular phenotype of the same tumor in different people may also vary. Thereby the sensitivity to targeted therapy may vary. (3) The activation of alternative pathways leads to immune escape. In clinical trials, only a small proportion of the clinical trials in malignant gliomas concurrently conducted pharmacokinetic studies and most of these studies collect blood samples to work out plasma clearance, rather than directly analysis of cerebrospinal fluid or drug concentration in tumor tissues. Collectively, there are all relevant restrictions to targeted therapy based on PI3K signal pathway.

\section{CONCLUSION \\ AND \\ FUTURE PROSPECTS}

As we have discussed here, PI3K/Akt/mTOR signal pathway after activation of EGFR is one of the most significant signal pathways in tumor cells. It has confirmed that it plays an important role in the genesis and development of glioma. At the moment, targeted therapy towards intracellular signal pathways has not achieved satisfactory result yet. A future perspective for GBM therapy is combination of multiple targets and personalized treatment. Although issues like cross-talk signal pathways or tumor heterogeneity tarnished the efficacy of therapy targeted PI3K/Akt/mTOR as we expected, we still believe that it will light up a new way in glioblastoma therapy. Recent study showed that targeting HSP90 and histone deacetylases could enhance the therapeutic effect of TMZ combined with radiotherapy [90].

\section{Abbreviations}

GBM: glioblastoma multiform, PI3K: phosphatidylinositol 3-kinase, mTOR: rapamycinsensitive mTOR-complex, EGFR: epidermal growth factor receptor, TMZ: temozolomide, RTKs: receptor tyrosine kinases, PTEN: phosphatase and tensin homolog deleted on chromosome ten, pS6k: ribosomal protein S6 kinase , eIF4E: eukaryotic initiation factor 4E, 4EBP1: eukaryotic initiation factor binding protein 1, PIP2: phosphatidylinositol-3, 4-bisphosphate, PIP3: phosphatidy linositol-3, 4, 5-bisphosphate, BBB: blood-brain-barrier, PDK1/2: phosphoinositide-dependent kinase $1 / 2$

\section{ACKNOWLEDGMENTS}

This work was supported by grants from the Natural Science Foundation of China to Xiaoman Li (81300800), Liang Wang (81302192) and Cao Liu (81130042 and 31171323); Liaoning research fund for higher education to Xiaoman Li (20131141) and Liang Wang (20141029); $\mathrm{Ph}$.D. Programs Foundation of Ministry of Education of China to Xiaoman Li (20132104120015).

\section{CONFLICTS OF INTEREST}

There is no conflict of interest.

\section{REFERENCES}

1. Olar A and Aldape KD. Using the molecular classification of glioblastoma to inform personalized treatment. J Pathol. 2014; 232:165-177.

2. Cloughesy TF, Cavenee WK and Mischel PS. Glioblastoma: from molecular pathology to targeted treatment. Annu Rev 
Pathol. 2014; 9:1-25.

3. Messaoudi K, Clavreul A and Lagarce F. Toward an effective strategy in glioblastoma treatment. Part II: RNA interference as a promising way to sensitize glioblastomas to temozolomide. Drug Discov Today. 2015; 20:772-779.

4. Stupp R, Mason WP, van den Bent MJ, Weller M, Fisher $\mathrm{B}$, Taphoorn MJ, Belanger K, Brandes AA, Marosi C, Bogdahn U, Curschmann J, Janzer RC, Ludwin SK, Gorlia T, Allgeier A, Lacombe D, et al. Radiotherapy plus concomitant and adjuvant temozolomide for glioblastoma. N Engl J Med. 2005; 352:987-996.

5. Ostrom QT, Gittleman H, Farah P, Ondracek A, Chen Y, Wolinsky Y, Stroup NE, Kruchko C and Barnholtz-Sloan JS. CBTRUS statistical report: Primary brain and central nervous system tumors diagnosed in the United States in 2006-2010. Neuro Oncol. 2013; 15 Suppl 2:ii1-56.

6. Stupp R, Hegi ME, Mason WP, van den Bent MJ, Taphoorn MJ, Janzer RC, Ludwin SK, Allgeier A, Fisher B, Belanger K, Hau P, Brandes AA, Gijtenbeek J, Marosi C, Vecht CJ, Mokhtari K, et al. Effects of radiotherapy with concomitant and adjuvant temozolomide versus radiotherapy alone on survival in glioblastoma in a randomised phase III study: 5-year analysis of the EORTC-NCIC trial. Lancet Oncol. 2009; 10:459-466.

7. Stupp R, Hegi ME, Neyns B, Goldbrunner R, Schlegel U, Clement PM, Grabenbauer GG, Ochsenbein AF, Simon M, Dietrich PY, Pietsch T, Hicking C, Tonn JC, Diserens AC, Pica A, Hermisson M, et al. Phase I/IIa study of cilengitide and temozolomide with concomitant radiotherapy followed by cilengitide and temozolomide maintenance therapy in patients with newly diagnosed glioblastoma. J Clin Oncol. 2010; 28:2712-2718.

8. Network TC. Corrigendum: Comprehensive genomic characterization defines human glioblastoma genes and core pathways. Nature. 2013; 494:506.

9. Douglas DA, Zhong H, Ro JY, Oddoux C, Berger AD, Pincus MR, Satagopan JM, Gerald WL, Scher HI, Lee P and Osman I. Novel mutations of epidermal growth factor receptor in localized prostate cancer. Front Biosci. 2006; 11:2518-2525.

10. Samuels Y, Wang Z, Bardelli A, Silliman N, Ptak J, Szabo S, Yan H, Gazdar A, Powell SM, Riggins GJ, Willson JK, Markowitz S, Kinzler KW, Vogelstein B and Velculescu VE. High frequency of mutations of the PIK3CA gene in human cancers. Science. 2004; 304:554.

11. Parsons DW, Jones S, Zhang X, Lin JC, Leary RJ, Angenendt P, Mankoo P, Carter H, Siu IM, Gallia GL, Olivi A, McLendon R, Rasheed BA, Keir S, Nikolskaya T, Nikolsky Y, et al. An integrated genomic analysis of human glioblastoma multiforme. Science. 2008; 321:1807-1812.

12. Samuels Y, Diaz LA, Jr., Schmidt-Kittler O, Cummins JM, Delong L, Cheong I, Rago C, Huso DL, Lengauer C, Kinzler KW, Vogelstein B and Velculescu VE. Mutant PIK3CA promotes cell growth and invasion of human cancer cells. Cancer Cell. 2005; 7:561-573.
13. Chakravarti A, Zhai G, Suzuki Y, Sarkesh S, Black PM, Muzikansky A and Loeffler JS. The prognostic significance of phosphatidylinositol 3-kinase pathway activation in human gliomas. J Clin Oncol. 2004; 22:1926-1933.

14. Liu P, Cheng H, Roberts TM and Zhao JJ. Targeting the phosphoinositide 3-kinase pathway in cancer. Nat Rev Drug Discov. 2009; 8:627-644.

15. Courtney KD, Corcoran RB and Engelman JA. The PI3K pathway as drug target in human cancer. J Clin Oncol. 2010; 28:1075-1083.

16. Engelman JA. Targeting PI3K signalling in cancer: opportunities, challenges and limitations. Nat Rev Cancer. 2009; 9:550-562.

17. Burris HA, 3rd. Overcoming acquired resistance to anticancer therapy: focus on the PI3K/AKT/mTOR pathway. Cancer Chemother Pharmacol. 2013; 71:829-842.

18. Wen PY and Kesari S. Malignant gliomas in adults. N Engl J Med. 2008; 359:492-507.

19. Sami A and Karsy M. Targeting the PI3K/AKT/mTOR signaling pathway in glioblastoma: novel therapeutic agents and advances in understanding. Tumour Biol. 2013; 34:1991-2002.

20. Mellinghoff IK, Wang MY, Vivanco I, Haas-Kogan DA, Zhu S, Dia EQ, Lu KV, Yoshimoto K, Huang JH, Chute DJ, Riggs BL, Horvath S, Liau LM, Cavenee WK, Rao PN, Beroukhim R, et al. Molecular determinants of the response of glioblastomas to EGFR kinase inhibitors. N Engl J Med. 2005; 353:2012-2024.

21. Chakravarti A, Dicker A and Mehta M. The contribution of epidermal growth factor receptor (EGFR) signaling pathway to radioresistance in human gliomas: a review of preclinical and correlative clinical data. Int J Radiat Oncol Biol Phys. 2004; 58:927-931.

22. Zhang H, Berezov A, Wang Q, Zhang G, Drebin J, Murali R and Greene MI. ErbB receptors: from oncogenes to targeted cancer therapies. Journal of Clinical Investigation. 2007; 117:2051-2058.

23. Huang PH, Xu AM and White FM. Oncogenic EGFR signaling networks in glioma. Sci Signal. 2009; 2:re6.

24. Engelman JA, Luo J and Cantley LC. The evolution of phosphatidylinositol 3-kinases as regulators of growth and metabolism. Nat Rev Genet. 2006; 7:606-619.

25. Riehle RD, Cornea $\mathrm{S}$ and Degterev A. Role of phosphatidylinositol 3,4,5-trisphosphate in cell signaling. Adv Exp Med Biol. 2013; 991:105-139.

26. Smith JS, Tachibana I, Passe SM, Huntley BK, Borell TJ, Iturria N, O'Fallon JR, Schaefer PL, Scheithauer BW, James CD, Buckner JC and Jenkins RB. PTEN mutation, EGFR amplification, and outcome in patients with anaplastic astrocytoma and glioblastoma multiforme. J Natl Cancer Inst. 2001; 93:1246-1256.

27. Sarbassov DD, Guertin DA, Ali SM and Sabatini DM. Phosphorylation and regulation of Akt/PKB by the rictormTOR complex. Science. 2005; 307:1098-1101. 
28. Hay N. Interplay between FOXO, TOR, and Akt. Biochim Biophys Acta. 2011; 1813:1965-1970.

29. Guertin DA and Sabatini DM. An expanding role for mTOR in cancer. Trends Mol Med. 2005; 11:353-361.

30. Guertin DA and Sabatini DM. Defining the role of mTOR in cancer. Cancer Cell. 2007; 12:9-22.

31. Jhanwar U. Involvement of mTORC1 and mTORC2 in regulation of glioblastoma multiforme growth and motility. International Journal of Oncology. 2009; 35:731-40.

32. Wu SH, Bi JF, Cloughesy T, Cavenee WK and Mischel PS. Emerging function of mTORC2 as a core regulator in glioblastoma: metabolic reprogramming and drug resistance. Cancer Biol Med. 2014; 11:255-263.

33. Dowling RJ, Topisirovic I, Fonseca BD and Sonenberg N. Dissecting the role of mTOR: lessons from mTOR inhibitors. Biochim Biophys Acta. 2010; 1804:433-439.

34. Hay N and Sonenberg N. Upstream and downstream of mTOR. Genes Dev. 2004; 18:1926-1945.

35. Fan Q-W and Weiss WA. Inhibition of PI3K-Akt-mTOR Signaling in Glioblastoma by mTORC1/2 Inhibitors. 2012; 821:349-359.

36. Nishikawa R, Ji XD, Harmon RC, Lazar CS, Gill GN, Cavenee WK and Huang HJ. A mutant epidermal growth factor receptor common in human glioma confers enhanced tumorigenicity. Proc Natl Acad Sci U S A. 1994; 91:77277731.

37. Szerlip NJ, Pedraza A, Chakravarty D, Azim M, McGuire J, Fang Y, Ozawa T, Holland EC, Huse JT, Jhanwar $\mathrm{S}$, Leversha MA, Mikkelsen $\mathrm{T}$ and Brennan $\mathrm{CW}$. Intratumoral heterogeneity of receptor tyrosine kinases EGFR and PDGFRA amplification in glioblastoma defines subpopulations with distinct growth factor response. Proceedings of the National Academy of Sciences. 2012; 109:3041-3046.

38. Hegi ME, Diserens AC, Bady P, Kamoshima Y, Kouwenhoven MC, Delorenzi M, Lambiv WL, Hamou MF, Matter MS, Koch A, Heppner FL, Yonekawa Y, Merlo A, Frei K, Mariani L and Hofer S. Pathway analysis of glioblastoma tissue after preoperative treatment with the EGFR tyrosine kinase inhibitor gefitinib - a phase II trial. Mol Cancer Ther. 2011; 10:1102-1112.

39. van den Bent MJ, Brandes AA, Rampling R, Kouwenhoven MC, Kros JM, Carpentier AF, Clement PM, Frenay M, Campone M, Baurain JF, Armand JP, Taphoorn MJ, Tosoni A, Kletzl H, Klughammer B, Lacombe D, et al. Randomized phase II trial of erlotinib versus temozolomide or carmustine in recurrent glioblastoma: EORTC brain tumor group study 26034. J Clin Oncol. 2009; 27:12681274 .

40. Brown PD, Krishnan S, Sarkaria JN, Wu W, Jaeckle KA, Uhm JH, Geoffroy FJ, Arusell R, Kitange G, Jenkins RB, Kugler JW, Morton RF, Rowland KM, Jr., Mischel P, Yong WH, Scheithauer BW, et al. Phase I/II trial of erlotinib and temozolomide with radiation therapy in the treatment of newly diagnosed glioblastoma multiforme: North Central Cancer Treatment Group Study N0177. J Clin Oncol. 2008; 26:5603-5609

41. Peereboom DM, Shepard DR, Ahluwalia MS, Brewer CJ, Agarwal N, Stevens GH, Suh JH, Toms SA, Vogelbaum MA, Weil RJ, Elson P and Barnett GH. Phase II trial of erlotinib with temozolomide and radiation in patients with newly diagnosed glioblastoma multiforme. J Neurooncol. 2010; 98:93-99.

42. Sathornsumetee S, Desjardins A, Vredenburgh JJ, McLendon RE, Marcello J, Herndon JE, Mathe A, Hamilton M, Rich JN, Norfleet JA, Gururangan S, Friedman HS and Reardon DA. Phase II trial of bevacizumab and erlotinib in patients with recurrent malignant glioma. Neuro Oncol. 2010; 12:1300-1310.

43. Westhoff MA, Karpel-Massler G, Bruhl O, Enzenmuller S, La Ferla-Bruhl K, Siegelin MD, Nonnenmacher L and Debatin KM. A critical evaluation of PI3K inhibition in Glioblastoma and Neuroblastoma therapy. Mol Cell Ther. $2014 ; 2: 32$.

44. Powis G, Berggren M, Gallegos A, Frew T, Hill S, Kozikowski A, Bonjouklian R, Zalkow L, Abraham $\mathrm{R}$, Ashendel $\mathrm{C}$ and et al. Advances with phospholipid signalling as a target for anticancer drug development. Acta Biochim Pol. 1995; 42:395-403.

45. Knight ZA and Shokat KM. Chemically targeting the PI3K family. Biochem Soc Trans. 2007; 35:245-249.

46. Vlahos CJ, Matter WF, Hui KY and Brown RF. A specific inhibitor of phosphatidylinositol 3-kinase, 2-(4-morpholinyl)-8-phenyl-4H-1-benzopyran-4-one (LY294002). J Biol Chem. 1994; 269:5241-5248.

47. Powis G, Bonjouklian R, Berggren MM, Gallegos A, Abraham R, Ashendel C, Zalkow L, Matter WF, Dodge J, Grindey $\mathrm{G}$ and et al. Wortmannin, a potent and selective inhibitor of phosphatidylinositol-3-kinase. Cancer Res. 1994; 54:2419-2423.

48. Hartmann W, Digon-Sontgerath B, Koch A, Waha A, Endl E, Dani I, Denkhaus D, Goodyer CG, Sorensen N, Wiestler OD and Pietsch T. Phosphatidylinositol 3'-kinase/AKT signaling is activated in medulloblastoma cell proliferation and is associated with reduced expression of PTEN. Clin Cancer Res. 2006; 12:3019-3027.

49. Guerreiro AS, Fattet S, Fischer B, Shalaby T, Jackson SP, Schoenwaelder SM, Grotzer MA, Delattre O and Arcaro A. Targeting the PI3K p110alpha isoform inhibits medulloblastoma proliferation, chemoresistance, and migration. Clin Cancer Res. 2008; 14:6761-6769.

50. Bendell JC, Rodon J, Burris HA, de Jonge M, Verweij J, Birle D, Demanse D, De Buck SS, Ru QC, Peters M, Goldbrunner $\mathrm{M}$ and Baselga J. Phase I, dose-escalation study of BKM120, an oral pan-Class I PI3K inhibitor, in patients with advanced solid tumors. J Clin Oncol. 2012; $30: 282-290$

51. Koul D, Fu J, Shen R, LaFortune TA, Wang S, Tiao N, 
Kim YW, Liu JL, Ramnarian D, Yuan Y, Garcia-Echevrria C, Maira SM and Yung WK. Antitumor activity of NVPBKM120 - a selective pan class I PI3 kinase inhibitor showed differential forms of cell death based on p53 status of glioma cells. Clin Cancer Res. 2012; 18:184-195.

52. Wen PY, Lee EQ, Reardon DA, Ligon KL and Alfred Yung WK. Current clinical development of PI3K pathway inhibitors in glioblastoma. Neuro Oncol. 2012; 14:819-829.

53. Huang TT, Sarkaria SM, Cloughesy TF and Mischel PS. Targeted therapy for malignant glioma patients: lessons learned and the road ahead. Neurotherapeutics. 2009; 6:500-512.

54. Ihle NT, Williams R, Chow S, Chew W, Berggren MI, Paine-Murrieta G, Minion DJ, Halter RJ, Wipf P, Abraham R, Kirkpatrick L and Powis G. Molecular pharmacology and antitumor activity of PX-866, a novel inhibitor of phosphoinositide-3-kinase signaling. Mol Cancer Ther. 2004; 3:763-772.

55. Koul D, Shen R, Kim YW, Kondo Y, Lu Y, Bankson J, Ronen SM, Kirkpatrick DL, Powis G and Yung WK. Cellular and in vivo activity of a novel PI3K inhibitor, PX-866, against human glioblastoma. Neuro Oncol. 2010; 12:559-569.

56. Pitz MW, Eisenhauer EA, MacNeil MV, Thiessen B, Easaw JC, Macdonald DR, Eisenstat DD, Kakumanu AS, Salim M, Chalchal H, Squire J, Tsao MS, Kamel-Reid S, Banerji S, Tu D, Powers J, et al. Phase II study of PX-866 in recurrent glioblastoma. Neuro Oncol. 2015; 17:1270-1274.

57. Robinson JP, Vanbrocklin MW, McKinney AJ, Gach HM and Holmen SL. Akt signaling is required for glioblastoma maintenance in vivo. Am J Cancer Res. 2011; 1:155-167.

58. Bader AG, Kang S and Vogt PK. Cancer-specific mutations in PIK3CA are oncogenic in vivo. Proc Natl Acad Sci U S A. 2006; 103:1475-1479.

59. Momota H, Nerio E and Holland EC. Perifosine Inhibits Multiple Signaling Pathways in Glial Progenitors and Cooperates With Temozolomide to Arrest Cell Proliferation in Gliomas In vivo. Cancer Res. 2005; 65:7429-7435.

60. Yap TA, Garrett MD, Walton MI, Raynaud F, de Bono JS and Workman P. Targeting the PI3K-AKT-mTOR pathway: progress, pitfalls, and promises. Curr Opin Pharmacol. 2008; 8:393-412.

61. Ghobrial IM, Roccaro A, Hong F, Weller E, Rubin N, Leduc R, Rourke M, Chuma S, Sacco A, Jia X, Azab F, Azab AK, Rodig S, Warren D, Harris B, Varticovski L, et al. Clinical and translational studies of a phase II trial of the novel oral Akt inhibitor perifosine in relapsed or relapsed/ refractory Waldenstrom's macroglobulinemia. Clin Cancer Res. 2010; 16:1033-1041.

62. Gao Q, Lei T and Ye F. Therapeutic targeting of EGFRactivated metabolic pathways in glioblastoma. Expert Opin Investig Drugs. 2013; 22:1023-1040.

63. Joy AM, Beaudry CE, Tran NL, Ponce FA, Holz DR, Demuth $\mathrm{T}$ and Berens ME. Migrating glioma cells activate the PI3-K pathway and display decreased susceptibility to apoptosis. J Cell Sci. 2003; 116:4409-4417.

64. Wang $\mathrm{G}$, Kang $\mathrm{C}$ and $\mathrm{Pu}$ P. Increased expression of Akt2 and activity of PI3K and cell proliferation with the ascending of tumor grade of human gliomas. Clin Neurol Neurosurg. 2010; 112:324-327.

65. Markman B, Dienstmann R and Tabernero J. Targeting the $\mathrm{PI}$ K/Akt/mTOR pathway — beyond rapalogs. Oncotarget. 2010; 1:530-543. doi: 10.18632/oncotarget.188.

66. Cloughesy TF, Yoshimoto K, Nghiemphu P, Brown K, Dang J, Zhu S, Hsueh T, Chen Y, Wang W, Youngkin D, Liau L, Martin N, Becker D, Bergsneider M, Lai A, Green $\mathrm{R}$, et al. Antitumor activity of rapamycin in a Phase I trial for patients with recurrent PTEN-deficient glioblastoma. PLoS Med. 2008; 5:e8.

67. Knobbe CB, Trampe-Kieslich A and Reifenberger G. Genetic alteration and expression of the phosphoinositol3-kinase/Akt pathway genes PIK3CA and PIKE in human glioblastomas. Neuropathol Appl Neurobiol. 2005; 31:486490.

68. Liu X, Hu Y, Hao C, Rempel SA and Ye K. PIKE-A is a proto-oncogene promoting cell growth, transformation and invasion. Oncogene. 2007; 26:4918-4927.

69. Mayo LD, Dixon JE, Durden DL, Tonks NK and Donner DB. PTEN protects $\mathrm{p} 53$ from Mdm2 and sensitizes cancer cells to chemotherapy. J Biol Chem. 2002; 277:5484-5489.

70. Tian XX, Zhang YG, Du J, Fang WG, Ng HK and Zheng J. Effects of cotransfection of antisense-EGFR and wild-type PTEN cDNA on human glioblastoma cells. Neuropathology. 2006; 26:178-187.

71. Chang SM, Wen P, Cloughesy T, Greenberg H, Schiff D, Conrad C, Fink K, Robins HI, De Angelis L, Raizer J, Hess K, Aldape K, Lamborn KR, Kuhn J, Dancey J and Prados MD. Phase II study of CCI-779 in patients with recurrent glioblastoma multiforme. Invest New Drugs. 2005; 23:357361.

72. Wen PY, Chang SM, Lamborn KR, Kuhn JG, Norden AD, Cloughesy TF, Robins HI, Lieberman FS, Gilbert MR, Mehta MP, Drappatz J, Groves MD, Santagata S, Ligon AH, Yung WK, Wright JJ, et al. Phase I/II study of erlotinib and temsirolimus for patients with recurrent malignant gliomas: North American Brain Tumor Consortium trial 04-02. Neuro Oncol. 2014; 16:567-578.

73. Reardon DA, Desjardins A, Vredenburgh JJ, Gururangan S, Friedman AH, Herndon JE, 2nd, Marcello J, Norfleet JA, McLendon RE, Sampson JH and Friedman HS. Phase 2 trial of erlotinib plus sirolimus in adults with recurrent glioblastoma. J Neurooncol. 2010; 96:219-230.

74. Hainsworth JD, Shih KC, Shepard GC, Tillinghast GW, Brinker BT and Spigel DR. Phase II study of concurrent radiation therapy, temozolomide, and bevacizumab followed by bevacizumab/everolimus as first-line treatment for patients with glioblastoma. Clin Adv Hematol Oncol. $2012 ; 10: 240-246$. 
75. Zhao L and Vogt PK. Helical domain and kinase domain mutations in p110alpha of phosphatidylinositol 3-kinase induce gain of function by different mechanisms. Proc Natl Acad Sci U S A. 2008; 105:2652-2657.

76. Carson JD, Van Aller G, Lehr R, Sinnamon RH, Kirkpatrick RB, Auger KR, Dhanak D, Copeland RA, Gontarek RR, Tummino PJ and Luo L. Effects of oncogenic p110alpha subunit mutations on the lipid kinase activity of phosphoinositide 3-kinase. Biochem J. 2008; 409:519-524.

77. Ben Sahra I, Regazzetti C, Robert G, Laurent K, Le Marchand-Brustel Y, Auberger P, Tanti JF, GiorgettiPeraldi S and Bost F. Metformin, independent of AMPK, induces mTOR inhibition and cell-cycle arrest through REDD1. Cancer Res. 2011; 71:4366-4372.

78. Masui K, Cavenee WK and Mischel PS. mTORC2 in the center of cancer metabolic reprogramming. Trends Endocrinol Metab. 2014; 25:364-373.

79. Jhanwar-Uniyal M, Gillick JL, Neil J, Tobias M, Thwing $\mathrm{ZE}$ and Murali R. Distinct signaling mechanisms of mTORC1 and mTORC2 in glioblastoma multiforme: a tale of two complexes. Adv Biol Regul. 2015; 57:64-74.

80. Chresta CM, Davies BR, Hickson I, Harding T, Cosulich S, Critchlow SE, Vincent JP, Ellston R, Jones D, Sini P, James D, Howard Z, Dudley P, Hughes G, Smith L, Maguire S, et al. AZD8055 Is a Potent, Selective, and Orally Bioavailable ATP-Competitive Mammalian Target of Rapamycin Kinase Inhibitor with In vitro and In vivo Antitumor Activity. Cancer Res. 2009; 70:288-298.

81. Marshall G, Howard Z, Dry J, Fenton S, Heathcote D, Gray N, Keen H, Logie A, Holt S, Smith P and Guichard Sylvie M. Benefits of mTOR kinase targeting in oncology: pre-clinical evidence with AZD8055. Biochemical Society Transactions. 2011; 39:456-459.

82. Luchman HA, Stechishin OD, Nguyen SA, Lun XQ, Cairncross JG and Weiss S. Dual mTORC1/2 blockade inhibits glioblastoma brain tumor initiating cells in vitro and in vivo and synergizes with temozolomide to increase orthotopic xenograft survival. Clin Cancer Res. 2014; 20:5756-5767.
83. Fan QW, Knight ZA, Goldenberg DD, Yu W, Mostov KE, Stokoe D, Shokat KM and Weiss WA. A dual PI3 kinase/ mTOR inhibitor reveals emergent efficacy in glioma. Cancer Cell. 2006; 9:341-349.

84. Bagci-Onder T, Wakimoto H, Anderegg M, Cameron $\mathrm{C}$ and Shah K. A Dual PI3K/mTOR Inhibitor, PI-103, Cooperates with Stem Cell-Delivered TRAIL in Experimental Glioma Models. Cancer Res. 2011; 71:154-163.

85. Haas-Kogan DA, Prados MD, Tihan T, Eberhard DA, Jelluma N, Arvold ND, Baumber R, Lamborn KR, Kapadia A, Malec M, Berger MS and Stokoe D. Epidermal growth factor receptor, protein kinase $\mathrm{B} / \mathrm{Akt}$, and glioma response to erlotinib. J Natl Cancer Inst. 2005; 97:880-887.

86. Halatsch ME, Schmidt U, Behnke-Mursch J, Unterberg A and Wirtz CR. Epidermal growth factor receptor inhibition for the treatment of glioblastoma multiforme and other malignant brain tumours. Cancer Treat Rev. 2006; 32:7489.

87. Stauffer F, Maira SM, Furet $\mathrm{P}$ and Garcia-Echeverria C. Imidazo[4,5-c]quinolines as inhibitors of the PI3K/PKBpathway. Bioorg Med Chem Lett. 2008; 18:1027-1030.

88. Maira SM, Stauffer F, Brueggen J, Furet P, Schnell C, Fritsch C, Brachmann S, Chene P, De Pover A, Schoemaker K, Fabbro D, Gabriel D, Simonen M, Murphy L, Finan P, Sellers W, et al. Identification and characterization of NVPBEZ235, a new orally available dual phosphatidylinositol 3-kinase/mammalian target of rapamycin inhibitor with potent in vivo antitumor activity. Mol Cancer Ther. 2008; 7:1851-1863.

89. Liu TJ, Koul D, LaFortune T, Tiao N, Shen RJ, Maira SM, Garcia-Echevrria C and Yung WKA. NVP-BEZ235, a novel dual phosphatidylinositol 3-kinase/mammalian target of rapamycin inhibitor, elicits multifaceted antitumor activities in human gliomas. Mol Cancer Ther. 2009; 8:2204-2210.

90. Choi EJ, Cho BJ, Lee DJ, Hwang YH, Chun SH, Kim HH and Kim IA. Enhanced cytotoxic effect of radiation and temozolomide in malignant glioma cells: targeting PI3KAKT-mTOR signaling, HSP90 and histone deacetylases. BMC Cancer. 2014; 14:17. 